The University of Maine

DigitalCommons@UMaine

Dr. Edward D. Ives Papers

Northeast Archives of Folklore and Oral History

1962

Satirical Songs in Maine and the Maritime Provinces of Canada

Edward D. Ives

Follow this and additional works at: https://digitalcommons.library.umaine.edu/ives_papers

Part of the Cultural History Commons, Folklore Commons, and the Oral History Commons

This Article is brought to you for free and open access by DigitalCommons@UMaine. It has been accepted for inclusion in Dr. Edward D. Ives Papers by an authorized administrator of DigitalCommons@UMaine. For more information, please contact um.library.technical.services@maine.edu. 


\title{
SATIRICAL SONGS IN MAINE AND THE MARITIME PROVINCES OF CANADA ${ }^{1}$
}

\author{
EDWARD D. IVES (University of Maine, Orono, Maine)
}

INVECTIVE, ridicule, and insult are not uncommon ingredients in folk songs, and since songs containing these elements usually make us laugh, we speak of them as satirical. Sometimes the satire springs from a strong sense of social injustice, as it did with singers like Aunt Molly Jackson and Woody Guthrie." More commonly it arises from personal motives, such as a desire to annoy. This is a progress report on local songs - particularly those attributed to Larry Gorman-in Maine, New Brunswick and Prince Edward Island.

There are many kinds of satire in folk song. At one end of the scale is the gentle kind found in the long lumbercamp "monicker" songs, where the joke is often obscure to an outsider; the other is the direct insult found in Larry Gorman's song on Michael McElroy:
Hail fishermen, for your own sake
I pray you all a warning take
And unto me a promise make
When going to seek employ;
And if you should fish another year
Or ever happen to come here,
Of one great bogus pray keep clear
He will rob and starve you all I fear, His name is McElroy.
He has a wife that is much the same Who glories in the swindling game; Were he to rob both blind and lame, She would laugh and shout with joy, His knavish tricks she does admire, She'll counsel with him and conspire She'll make the balls for him to fire, This Mistress McElroy.

Between, lie all shades of vilification. We must bear in mind that any folk song derives much of its effect from the social situation in which it is sung, and this depenence on context is intensified for a genre as topical as satire. What appears to us as outrageous insult, may have been intended (and accepted) as good-natured teasing. What appears to us a pleasant joke, may have been salt in an open wound for a listener. Sometimes a song derived all its intended effect from the situation. What could appear to be a more standard romantic ballad than "Jack Haggerty?" Yet Geraldine J. Chickering has shown that it may well have been written to embarrass someone who is not even mentioned in the song. ${ }^{3}$ For the present, let us define a satirical folk song as one that ridicules some local person, institution, or event.

That there formerly existed a tradition of satirical song-making in Maine and the Maritimes is known. ${ }^{4}$ Many seem to have tried their hand at making comical local songs that lived for a while and subsequently disappeared, unless by chance noted down. There were also more gifted men and women, recognized as poets, and some 
of these specialized in satire. In New Brunswick, along the Miramichi River, there was Martin Sullivan, the cow-doctor of Kouchibouguac, Jared MacLean of Starthadam, Joe Smith ("The Riving Joe") of Renous, Frank O'Hara and Isaac Underhill of Grey Rapids, Abraham Munn and Davey Hunter of Pleasant Ridge, and George and John Calhoun of Parker's Ridge-all of whom made up satirical songs that have entered the tradition, however limited that tradition may be. Finally, there was Larry Gorman, "the man who makes the songs," whose skill and wit are legendary in Prince Edward Island, New Brunswick, and Maine, wherever old woodsmen congregate. ${ }^{5}$

One of the most interesting points to emerge from this study has been the close association of any particular satire with a known satirist. Not only are most of the satirical songs collected known to have been composed by a particular person, but that very knowledge is often part of a song's tradition. That is to say, a singer is apt to introduce a song by explaining that Davey Hunter, or Joe Smith, or Larry Gorman made it. He may go on to explain why the song was written, and this explanation may or may not be historically correct. For example, Larry Gorman, while still living on Prince Edward Island, made up a song about a fisherman whom he called "The Gull Decoy." Here are two of the fifteen and more stanzas collected:

I raised my children to my own notions,

The eldest of them I called him Mick;

I always intended to give them tuition

To curse and swear and to cuff and kick.

The other day we got in a tussle,

'Twas then his mettle I thought I'd try;

But he knocked me down and he did me guzzle

And chewed the thumb off the Gull Decoy. ${ }^{6}$

Though written on Prince Edward Island, this song is well known in New Brunswick, especially along the Miramichi, where Larry worked for many years. Ask a local singer for it, and you are apt to be told, "That's the song Larry Gorman had to leave the Island for making up." Whether the information is correct or not (and it probably is not) it is part of the tradition of "The Gull Decoy." In fact, more people know about the song and its history than know the song itself. Thus the satirist and his legend may loom even larger than the song. As a further example of this emphasis on personality, one of the most characteristic types of material relating to Gorman is the short cante-fable - an anecdote with a clinching verse. For example: Larry was working for Michael McElroy, who ran a lobster factory. At that time all the canned lobster was shipped to England, and one day one of the shippers came to the factory, and McElroy invited him to lunch. Everyone ate at one long trestle table, and as they were preparing to sit down, McElroy said, "Larry, you say Grace." Larry looked down at his plate and said:

Oh Lord above, look down upon us

And see how we are forgotten;

And send us meat that is fit to eat,

Because By Christ, this is rotten.?

It is important that these cante-fables are in a form well qualified to swell the legend of the satirist and his wit. We have, then, not only a tradition of satirical songs by 
known authors, but at least two authors, Larry Gorman and Joe Smith, whose skill and deeds have themselves become legend.

It has been said that these woods-poets were men of influence, men to be feared. Eckstorm and Smyth seem to have been the first to express this opinion in print when, with regard to a song by Gorman on J. E. Henry \& Co. of New Hampshirea song generally known as "The Good Old State of Maine"-they wrote: ". . . what this song . . . has done in the way of keeping good men from going to New Hampshire to work is hard to estimate. Like 'Canaday-I-O' it was a warning to all who heard it, and the information it contained was sure to be remembered. The good employer, and the bad employer, celebrated in song, each had reason to respect the power of the woods poet; for he sent men to them or held them back from applying for work."s

William Doerflinger makes a similar suggestion. ${ }^{9}$ Up to the present, however, no evidence has been found that any employer suffered real injury at a satirist's hands. Rumour was much more effective, here as elsewhere. There are certainly instances where the song had no effect. John and Peter Jamieson (East Bathurst, New Brunswick), for example, had heard "The Good Old State of Maine" before they went to work for Henry. They learned the song, yet both men spoke very highly of Henry. Again, Gorman made a song about Roderick McDonald of Ellsworth, Maine, in which he accused him of stealing a dam-gate to secure water for his drive, and pilloried him as follows:

It's been forty years or nearly since he struck this town, He's always done the best he could to keep men's wages down.

He drove by the cords and thousands and hoarded up his dimes, And always hired his drivers cheap by preaching up hard times.

Roderick had no trouble in assembling a crew before or after that song appeared, nor did he dismiss Gorman for making it up. Again, Joe Smith made a song about one of Morgan Hayes' operations up Renous River; it did not put the Hayes outfit into receivership. If these woods-poets disturbed the labour market at all, this has still to be proved.

Doubtless these songs were often annoying. Roderick McDonald certainly did not like the song Gorman made up on him; and when Larry made up a song on Mack Dyer, calling him "The Great Pond Tramp," this so enraged the Dyer clan that Larry had to spend three days and nights in the woods until tempers cooled off. Many were annoyed by Joe Smith's songs, but since Joe was also one of the strongest and roughest men on the Miramichi River, their rage was impotent. To the question: whether or not men would get angry at being "songed," an old woodsman replied: "Sometimes, but as often as not they'd go out of their way to learn the damn thing." On the other hand, a man was threatened with a beating because he absent-mindedly hummed "The Gull Decoy" in the wrong place.

What can be learned from these songs regarding the process by which they came into being? First, does the same man write satires as writes ballads? For this area the answer in general is 'no,' but sometimes 'yes.' Larry Gorman never wrote a serious ballad, while Joe Scott, whose ballads are well-known in Maine and the Maritimes, never wrote a satire. John Calhoun, on the other hand, seems to have been able to do both. Is the folk-poet's gift one of spontaneous creation, or is a song the result of "private agony?" The evidence shows that Gorman was a careful craftsman, pacing the floor of his room, talking the poem over to himself, and 
sometimes writing it down as he went along; the Larry Gorman who fired off clever impromptu verses is almost pure legend. What was the position of a poet like Gorman in his community? He was "odd," he "wasn't the sort of a man you'd chose for a pal," he "wasn't like the other men." He was not, perhaps, an outsider looking in but an insider looking on, always a little on the edge of the crowd, watching. Did people come to him to get him to make up songs? Yes, but it was dangerous. Mike O'Brien on Prince Edward Island wanted him to make up a song on his brother, "Big Jim" O'Brien. Larry said he'd be damned if he'd make up a song on anyone who had used him as well as Big Jim had. Instead Larry made up a song on Mike. One day in Maine when Larry was sick in camp, Roderick McDonald came to him to ask him to make up a song on Frank Mace, the storekeeper. Instead, Larry wrote a song on Roderick. His songs were his private brickbats, and his grievances were his own, not others.' He was a man apart, and he neatly summed up his own position in "The Scow on Cowden Shore":
I have got many's the foe
And the same I well do know
So amongst them all I go
And it grieves their hearts full sore.
For I know that they could shoot me,
Cremenate or prosecute me,
But they kindly salute me
Round the scow on Cowden Shore. ${ }^{11}$

Thus light is thrown on the creative act and on the relation of a poet to his culture by the study of these local satirical songs.

While there were many who made up satirical songs, Larry Gorman was, and is by far, the best known. How is this explained? It is not that he was the most skilful songmaker; there are songs by others that are by any standards as good as, or better than Larry's. If Larry was a creator without rival, there should be no difficulty in distinguishing his productions from those of others. In fact, many songs have been attributed to him that he never wrote, and it may never be possible to establish a definitive canon. The explanation of his fame is, first, that Gorman was his own best press-agent:
And when they see me coming
Their eyes stick out like prongs
Saying, "Here comes Larry Gorman,
The man who makes the songs."

That verse, in a couple of dozen variants in many different contexts, probably did more to spread his fame than anything else he produced. Secondly, he lived his seventy years in two provinces and the State of Maine, while the other poets are closely associated with a single place. Thirdly, while others were woodsmen, riverdrivers, or mill-hands first, and poets in off hours, Larry Gorman was poet first and last; he was constantly at work on his songs. "You'd meet him on the street and be talking to him and suddenly his eyes would light up and he'd smile and you'd know you'd made him think of something he could use in a song." He never stopped, not even in church; hence his presence was a constant source of apprehension. While not denying his skill as a songmaker, that skill alone cannot explain his renown. "The man who makes the songs" aimed to make certain that people remembered not only the songs but also the man. He succeeded in both. 


\section{NOTES}

r. The author's thanks are due to the Coe Research Fund Committee of the University of Maine, and to the Research Committee of Indiana University, for financial assistance while collecting the material on which this paper is based.

2. John Greenway, American Folksongs of Protest, Philadelphia, 1953, passim.

3. Geraldine J. Chickering, "The Origin of a Ballad," Modern Language Notes, L. I935, $465-568$

4. William M. Doerflinger, Shantymen and Shantyboys, New York, I95I. See particularly his chapter nine, "Satirists of the Sawdust Country," pp. 253-69.

5. For further information on Larry Gorman, see my article, "The Life and Work of Larry Gorman: A Preliminary Report," Western Folklore, XIX, 1960, I7-23.

6. From the singing of John B. Stymiest of Tabusintac, New Brunswick, as recorded by Louise Manny for the Lord Beaverbrook Collection of New Brunswick Folksong.

7. For a collection of these canle-fables about Larry Gorman, see my article, "Larry Gorman and the Canle-Fable," New England Quarterly, XXXII, 1959, 226-237.

8. Fannie Hardy Eckstorm and Mary W. Smyth, Minstrelsy of Maine, Boston and New York, I927, p. II 3 .

9. Doerflinger, op. cit., p. 215.

ro. See my article, "Ben Deane' and Joe Scott: A Ballad and its Probable Author," Journal of American Folklore, LXXII, I959, 53-66.

II. From the singing of Fred McMahon of Chatham, New Brunswick, as recorded by Louise Manny for the Lord Beaverbrook Collection of New Brunswick Folksong.

Dr. P. J. Stephens (New York) asked when Gorman lived, and whether the satirical song tradition was still alive.

Mr. IVES replied that Gorman lived from I 846 to I9I7. While hesitating to say that the tradition was dead, he could say with confidence that there was not much of it.

Dr. H. CREighton (Dartmouth, Nova Scotia) suggested that folk singers in general make use of the improvised satirical song. She knew cases of singers who "song" their debtors in order to shame them into paying their debts.

Mr. H. HAUFREChT (Somerset, N.Y.) asked if there were evidence of local transposition of stories. In the Catskills, for example, there were local versions of Eulenspiegel and Münchhausen stories.

Mr. Ives replied that this occurs, and cited a version of the "grace before meat" story.

Dr. G. LIsT (Bloomington, Indiana) asked what a singer does in making a satirical song.

Mr. IVES replied that Larry Gorman would take a known tune, often a tune which by association itself augmented the satire through an added sense of parody.

Miss L. MANNy (Newcastle, New Brunswick) emphasized that Larry Gorman never made up a tune, and Mr. Ives corroborated this.

Mr. F. M. Collinson (Innerleithen, Scotland) mentioned instances where a tune was so strongly associated with a particular satirical song that it was dangerous even to whistle or hum it; he cited the case of a piper killed for playing such a tune.

Mr. Ives said there was an important distinction to be made between extemporized satire and the composed satire of Larry Gorman.

Mr. HAUfRECHT, referring to practices in the Catskills, said that while existing tunes might be used, in some instances fragments of tunes were put together to make a new tune. 